Article

\title{
Potential Use of Copper-Contaminated Soils for Hemp (Cannabis sativa L.) Cultivation
}

\author{
Giulia Quagliata ${ }^{1}$, Silvia Celletti ${ }^{1, *(\mathbb{D})}$, Eleonora Coppa ${ }^{1}$, Tanja Mimmo ${ }^{2,3}{ }^{\mathbb{D}}$, Stefano Cesco ${ }^{2}$ (D) \\ and Stefania Astolfi ${ }^{1}$ (D)
}

1 Department of Agricultural and Forestry Sciences (DAFNE), University of Tuscia, 01100 Viterbo, Italy; giuqua94@gmail.com (G.Q.); eleonoracoppa@libero.it (E.C.); sastolfi@unitus.it (S.A.)

2 Faculty of Science and Technology, Free University of Bozen-Bolzano, 39100 Bolzano, Italy; tanja.mimmo@unibz.it (T.M.); stefano.cesco@unibz.it (S.C.)

3 Competence Centre for Plant Health, Free University of Bozen-Bolzano, 39100 Bolzano, Italy

* Correspondence: silvia.celletti@unitus.it; Tel.: +39-076-135-7337

Citation: Quagliata, G.; Celletti, S.;

Coppa, E.; Mimmo, T.; Cesco, S.;

Astolfi, S. Potential Use of

Copper-Contaminated Soils for

Hemp (Cannabis sativa L.) Cultivation.

Environments 2021, 8, 111. https://

doi.org/10.3390/environments8110111

Academic Editor: Paula Alvarenga

Received: 8 September 2021

Accepted: 15 October 2021

Published: 20 October 2021

Publisher's Note: MDPI stays neutral with regard to jurisdictional claims in published maps and institutional affiliations.

Copyright: (c) 2021 by the authors. Licensee MDPI, Basel, Switzerland. This article is an open access article distributed under the terms and conditions of the Creative Commons Attribution (CC BY) license (https:// creativecommons.org/licenses/by/ $4.0 /)$.

\begin{abstract}
To mitigate climate change, reducing greenhouse gas emissions can be achieved by decreasing the use of fossil fuels and increasing that of alternative sources, such as energy crops. However, one of the most important problems in the use of biomass as a fuel is that of changing soil use and consumption, leading to competition with food crops. We addressed the topic by evaluating the possibility to exploit contaminated areas for energy crops cultivation. Indeed, soil contamination makes land inappropriate for cultivation, with damaging consequences for ecosystems, as well as posing serious health hazards to living beings. Specifically, this work aimed to evaluate the ability of hemp (Cannabis sativa L.) plants to grow on a copper $(\mathrm{Cu}$ )-contaminated medium. In addition, the effectiveness of an environment-friendly treatment with sulfate in improving plant ability to cope with $\mathrm{Cu}$-induced oxidative stress was also explored. Results showed that plants were able to grow at high $\mathrm{Cu}$ concentrations. Therefore, hemp could represent an interesting energy crop in $\mathrm{Cu}$-contaminated soils. Although the response of $\mathrm{Cu}$-treated plants was evidenced by the increase in thiol content, following modulation of sulfur metabolism, it remains to be clarified whether the use of exogenous sulfate could be an agronomic practice to improve crop performance under these edaphic conditions.
\end{abstract}

Keywords: biofuel; Cannabis sativa L.; climate change; copper; sulfur; sustainability

\section{Introduction}

The limitation of greenhouse gases emission is considered a priority for the mitigation of global warming and climate change. In order to meet this challenge, a remarkable replacement of fossil fuels for energy purposes in favor of renewable sources, like energy crops, as also recommended by the European community with the Directive 2009/28/EC [1], appears to be crucial. However, the cultivation of energy crops poses several issues, such as land-use change. In fact, when virgin land areas are considered, land conversion from natural ecosystems is clearly counter-productive, considering the environmental impact and specifically the loss of biodiversity in the soil-plant system [2]. In addition, soil consumption can be unequivocally considered as one of today's major challenges of agriculture. Indeed, the greater the demand for biomass from energy crops to achieve the EU goal, the larger the land surface to be dedicated to the cultivation of these plant species, thus giving rise to a sort of competition in the use of arable land for food or non-food purposes [3].

Facing the challenge of food security and safety for a growing population while preserving the environment highlights how crucial are these choices. However, the possibility of using abandoned or impaired fertility soils (i.e., so-called marginal soils) for energy crops could undoubtedly contribute to reducing the food/energy conflict in agricultural production [4]. In fact, it is well-known how some industrial activities and/or agricultural 
practices (e.g., the excessive use of agrochemicals for crop fertilization or protection against pathogens as well as the massive application of low-quality soil amendments), have sometimes compromised soil fertility, making soils partially or completely inappropriate for staple food production [5].

In particular, soil contamination with heavy metals, including both essential and non-essential metals, is a widespread issue posing environmental, animal, and human health risks [6]. A typical example is represented by copper $(\mathrm{Cu})$, an essential micronutrient with fundamental roles played in plants [7] as well as a component of different agrochemicals applied for the control of fungal pathogens of different crops, particularly perennial ones [8].

The continuous and extensive application of $\mathrm{Cu}$-based agrochemicals has led to a massive, and even alarming, long-term accumulation of this heavy metal in soils [9]. Specifically, in vineyard soils, $\mathrm{Cu}$ concentrations often exceed the limits set by European legislation for agricultural soils (ranging from 150-200 $\mathrm{mg} \mathrm{kg}^{-1}$ ) [10,11], even reaching levels up to approximately ten times higher [12].

In this respect, although levels of metal availability to plants in soil are strictly dependent on soil properties (e.g., cation exchange capacity, $\mathrm{pH}$, organic matter, and clay content) [13], it should be highlighted that the above-mentioned $\mathrm{Cu}$ levels could undoubtedly represent a significant threat to soil use [14]. In fact, a range of toxic phenomena, leading to reduced crop yield and quality, have been described in soils with $\mathrm{Cu}$ bioavailability significantly higher than $20 \mathrm{mg} \mathrm{kg}^{-1}$ [15].

Excess $\mathrm{Cu}$ induces the production of high levels of reactive oxygen species (ROS), which cause oxidative degradation of cell membrane lipids, resulting in the leakage of the cell contents, and affects photosynthetic functions [16]. Furthermore, excess $\mathrm{Cu}$ interferes with the acquisition processes of other nutrients [17-21], leading to nutritional imbalances [22]. For instance, being sulfur (S) directly involved in the oxidative stress response, plants exposed to high $\mathrm{Cu}$ concentrations usually show an enhanced demand for $S$ to sustain the increased production of thiols (mainly glutathione), which are the main plant antioxidants and heavy metal chelators implicated in detoxification [8,23]. Therefore, it is very likely that a higher $S$ availability in soil could be a valuable strategy allowing plant to counteract oxidative stress induced by high $\mathrm{Cu}$ levels.

Based on these premises, the present work aimed at evaluating the possibility of exploiting $\mathrm{Cu}$-contaminated soils for the cultivation of energy crops. Hemp (Cannabis sativa L.) was selected as a model plant for this study due to its high tolerance to biotic and abiotic stresses, leading it to good adaption to different soils and climatic conditions, and high biomass production.

In the last twenty years, several studies have investigated the possible use of hemp to clean up highly polluted soils [24]. These studies reported that hemp is extremely efficient to take up and accumulate heavy metals such as cadmium, lead, nickel, and zinc; however, very few studies described the use of hemp for the phytoremediation of $\mathrm{Cu}$-contaminated soils $[25,26]$.

We also tested the hypothesis that an environment-friendly treatment with exogenous sulfate could enhance plant tolerance to $\mathrm{Cu}$ toxicity, mainly by improving plant ability to cope with oxidative stress under $\mathrm{Cu}$ contamination.

\section{Materials and Methods}

\subsection{Plant Growing Conditions}

Hemp (Cannabis sativa L. cv Tisza) seeds were soaked in distilled water for $1 \mathrm{~h}$ and allowed to germinate in moistened filter paper in the dark at $28{ }^{\circ} \mathrm{C}$ for 7 days. Homogeneous seedlings were selected and transferred in hydroponic culture in 2-L black pots (6 seedlings/pot), containing a nutrient solution (NS) with the following composition (mM): $\mathrm{Ca}\left(\mathrm{NO}_{3}\right)_{2} \times 4 \mathrm{H}_{2} \mathrm{O} 2.0, \mathrm{KCl} 0.1, \mathrm{KH}_{2} \mathrm{PO}_{4} 0.1, \mathrm{~K}_{2} \mathrm{SO}_{4} 0.7, \mathrm{MgSO}_{4} \times 7 \mathrm{H}_{2} \mathrm{O} 0.5$, $\mathrm{CuSO}_{4} \times 5 \mathrm{H}_{2} \mathrm{O} 0.2 \times 10^{-3}, \mathrm{Fe}^{3+}$-EDTA $40 \times 10^{-3}, \mathrm{H}_{3} \mathrm{BO}_{3} 1 \times 10^{-3}, \mathrm{MnSO}_{4} \times \mathrm{H}_{2} \mathrm{O} 0.5 \times 10^{-3}$, $\left(\mathrm{NH}_{4}\right)_{6} \mathrm{Mo}_{7} \mathrm{O}_{24} \times 4 \mathrm{H}_{2} \mathrm{O} 0.01 \times 10^{-3}$, and $\mathrm{ZnSO}_{4} \times 7 \mathrm{H}_{2} \mathrm{O} 0.5 \times 10^{-3}$. After 14 days of 
growth, hemp seedlings were exposed to excess $\mathrm{Cu}$ and/or sulfate treatment, as follows: control $\left(\mathrm{C}=1.2 \mathrm{mM}\right.$ sulfate and $\left.0.2 \mu \mathrm{M} \mathrm{CuSO}_{4}\right)$; sulfate treatment $(\mathrm{ES}=2.4 \mathrm{mM}$ sulfate and $\left.0.2 \mu \mathrm{M} \mathrm{CuSO}_{4}\right)$; excess $\mathrm{Cu}\left(+\mathrm{Cu}=1.2 \mathrm{mM}\right.$ sulfate and $\left.20 \mu \mathrm{M} \mathrm{CuSO}_{4}\right)$; excess $\mathrm{Cu}$ and sulfate treatment $\left(\mathrm{ES}+\mathrm{Cu}=2.4 \mathrm{mM}\right.$ sulfate and $\left.20 \mu \mathrm{M} \mathrm{CuSO}_{4}\right)$. Applied sulfate concentrations were chosen based on previous study [27]. Plants were grown in a climate chamber with the following conditions: day $16 \mathrm{~h}, 28^{\circ} \mathrm{C}$; night $8 \mathrm{~h}, 20^{\circ} \mathrm{C}$; light intensity of $200 \mu \mathrm{E} \mathrm{m}^{-2} \mathrm{~s}^{-1}$. The NS was renewed every 3 days. After 21 days of growth in hydroponics, plants were harvested, the shoot and root fresh weights (FWs) were recorded, and the following experiments were performed.

\subsection{Chlorophyll Content}

At harvest (21 days of growth), chlorophyll content was measured in attached leaves of hemp plants using a non-destructive portable apparatus, the Soil Plant Analysis Development (SPAD—502 Plus, Konica Minolta, Osaka, Japan). Three independent measurements within each treatment were detected on the youngest fully expanded leaf, averaged, and expressed as SPAD units.

\subsection{Determination of Nutrient Concentration}

The nutrient concentration was determined according to the method described by [28]. Briefly, shoot and root samples were oven-dried at $65^{\circ} \mathrm{C}$ for $24 \mathrm{~h}$ and subsequently finely ground and homogenized with a ball mill (Mixer Mill, MM400, RETSCH, Pedrengo, BG, Italy). Approximately $0.3 \mathrm{~g}$ dry weight (DW) of each ground sample was mineralized in $4 \mathrm{~mL}$ concentrated ultrapure $\mathrm{HNO}_{3}\left(650 \mathrm{~mL} \mathrm{~L}^{-1}\right.$; Carlo Erba, Milan, Italy), using a single reaction chamber microwave digestion system (UltraWAVE, Milestone, Shelton, CT, USA). After cooling, the digested samples were diluted with Milli-Q water to $20 \mathrm{~mL}$. The concentrations of nutrients (i.e., calcium $-\mathrm{Ca}$, copper $-\mathrm{Cu}$, iron $-\mathrm{Fe}$, magnesium$\mathrm{Mg}$, manganese $-\mathrm{Mn}$, molybdenum $-\mathrm{Mo}$, phosphorus $-\mathrm{P}$, sulfur $-\mathrm{S}$, and zinc $-\mathrm{Zn}$ ) were measured three times, $12 \mathrm{~s}$ each, with $60 \mathrm{~s}$ of pre-running, using an inductively coupled plasma - optical emission spectroscopy (ICP-OES, Spectro Arcos, Spectro Ametek, Kleve, Germany) instrument, with an axial torch and high salinity kit. The ICP-OES operating conditions are summarized in Table 1 . The Ca signal was measured at $184 \mathrm{~nm}$, the $\mathrm{Cu}$ at $325 \mathrm{~nm}$, the Fe signal at $260 \mathrm{~nm}$, the $\mathrm{Mg}$ at $279 \mathrm{~nm}$, the $\mathrm{Mn}$ at $258 \mathrm{~nm}$, the Mo at $380 \mathrm{~nm}$, the $P$ at $178 \mathrm{~nm}$, the $S$ at $182 \mathrm{~nm}$, and the $\mathrm{Zn}$ at $214 \mathrm{~nm}$. Spinach leaves (SRM 1570a) and tomato leaves (SRM 1573a) were used as external certified reference materials. The detection limits for each nutrient are reported as follows $\left(\mu \mathrm{g} \mathrm{L}^{-1}\right)$ : Ca 7.000, $\mathrm{Cu} 1.170, \mathrm{Fe} 0.135, \mathrm{Mg} 2.000$, Mn 0.034, Mo 20.2, P 11.000, S 11.000, and Zn 0.362.

Table 1. ICP-OES operating conditions.

$\begin{array}{cc}\text { Plasma Power }(\mathrm{kW}) & 1.4 \\ \text { Pump Speed }(\mathrm{Rpm}) & 30 \\ \text { Coolant Flow }\left(\mathrm{L} \mathrm{min}{ }^{-1}\right) & 14 \\ \text { Auxiliary Flow }\left(\mathrm{L} \mathrm{min}^{-1}\right) & 0.8 \\ \text { Nebulizer Flow }\left(\mathrm{L} \mathrm{min}^{-1}\right) & 0.95\end{array}$

\subsection{Determination of Malondialdehyde Content}

The level of lipid peroxidation was expressed as malondialdehyde (MDA) content and was determined as 2-thiobarbituric acid (TBA) reactive metabolites according to [29]. Briefly, frozen shoot and root samples $(0.5 \mathrm{~g} \mathrm{FW})$ were finely ground with liquid nitrogen and homogenized in $5 \mathrm{~mL}$ of an extraction solution containing $0.25 \%(w / v)$ TBA dissolved in $10 \%(w / v)$ trichloroacetic acid (TCA). The resulting extracts were heated at $95{ }^{\circ} \mathrm{C}$ for $30 \mathrm{~min}$ and then quickly cooled on ice. After centrifugation at $10,000 \times \mathrm{g}$ for $10 \mathrm{~min}$, the absorbance of the supernatant was measured at $532 \mathrm{~nm}$. Correction of non-specific turbidity was obtained by subtracting the absorbance value detected at $600 \mathrm{~nm}$. Finally, the level of lipid peroxidation was calculated using an extinction coefficient of $155 \mathrm{mM}^{-1} \mathrm{~cm}^{-1}$. 


\subsection{Non-Protein Thiols Extraction and Determination}

Water soluble non-protein thiol compounds were determined colorimetrically with 5,5'dithio-bis-(2-nitrobenzoic acid) (DTNB), following the procedure reported by [30]. Briefly, both shoot and root tissues (1 $\mathrm{g} \mathrm{FW})$ were ground in liquid nitrogen and extracted in $3 \mathrm{~mL}$ of a solution composed of $80 \mathrm{mM}$ TCA, $1 \mathrm{mM}$ ethylenediaminetetraacetic acid (EDTA), $0.15 \%(w / v)$ ascorbic acid, and 10\% $(w / v)$ polyvinylpolypyrrolidone (PVP). After a centrifugation step $\left(30 \mathrm{~min}\right.$ at $4000 \times g$ and $4{ }^{\circ} \mathrm{C}$ ), the supernatant was recovered, and the concentration of DTNB-reactive compounds was detected spectrophotometrically at $415 \mathrm{~nm}$.

\subsection{Extraction and Assay of OASTL Activity}

Frozen shoot and root tissue ( $1 \mathrm{~g} \mathrm{FW})$ of hemp plants were powdered in liquid nitrogen. Cold extraction buffer, containing $50 \mathrm{mM}$ HEPES- $\mathrm{KOH}$ ( $\mathrm{pH} 7.4), 5 \mathrm{mM} \mathrm{MgCl}$, $1 \mathrm{mM}$ EDTA, 10\% $(v / v)$ glycerol, $0.1 \%(v / v)$ Triton X-100, $5 \mathrm{mM}$ dithiothreitol, $1 \mathrm{mM}$ phenylmethylsulphonyl fluoride, and 1\% $(w / v)$ PVP, was added in a ratio of 1:7 $(w / v)$ for shoots and of 1:3 $(w / v)$ for roots. Following extraction steps were performed according to the method described by [30].

The extractable O-acetylserine(thiol)lyase (OASTL; EC 4.2.99.8) enzyme activity was assayed in shoot and root samples by detecting cysteine production as described by [30]. The protein content was estimated in shoot and root extracts by the protein-binding Coomassie Brilliant Blue G-250 dye method using bovine serum albumin as standard [31].

\subsection{Statistical Analysis}

The results are presented as mean \pm standard deviation (SD) of measurements carried out in triplicate $(n=3)$ and obtained from four independent treatments. All data were statistically analyzed by one-way analysis of variance (ANOVA) with least significant difference (LSD) test at $p<0.05$ by using the statistical software CoStat Version 6.45 (CoHort, Berkeley, CA, USA). Principle component analysis (PCA) was performed with PAST (PAleontological STatistics) software (Version 4.05 for Windows).

\section{Results}

\subsection{Plant Growth Rate, Chlorophyll Content and Nutritional Status}

Figure 1 shows the effect of $\mathrm{Cu}$ excess in the growing medium and/or sulfate treatment on the growth rate of hemp plants in terms of shoot and root fresh weights. The plant exposure to $\mathrm{Cu}$ stress (+Cu condition) significantly inhibited the shoot biomass accumulation $(-58 \%)$, as also clearly visible in the picture below Figure 1, compared to the control plants (C condition) (Figure 1). When Cu stress was coupled with sulfate treatment (ES+Cu condition), shoot growth inhibition was also clearly detected (although to a lesser extent: $-40 \%$ ) compared to the $C$ condition even if no significant difference were noted between the $\mathrm{ES}+\mathrm{Cu}$ and $+\mathrm{Cu}$ conditions (Figure 1). Plants exposed to the sole sulfate treatment (ES condition) did not significantly exhibit changes in growth rate at both shoot and root level when compared to the control (Figure. 1).

Leaf chlorosis is one of the earliest and distinct symptoms of plant $\mathrm{Cu}$ toxicity (Figure 1). In the present study, we found that exposure of hemp plants to $\mathrm{Cu}$ excess (sole or in combination with sulfate treatment) reduced the chlorophyll content and led to visible leaf chlorosis (Figure 1 and picture below Figure 1). As observed for plant growth, the ES condition did not significantly affect the chlorophyll content with respect to the control (Figure 1).

It is well-known that excess $\mathrm{Cu}$ interferes with nutrient uptake, leading to nutritional imbalances.

Total S concentration increased by $153 \%$ only in roots of plants exposed to sole sulfate treatment (ES condition) (Figure 2A). In addition, $\mathrm{Cu}$ treatment (sole or in combination with sulfate treatment) did not significantly impact $S$ accumulation in both shoots and roots of hemp plants (Figure 2A). 

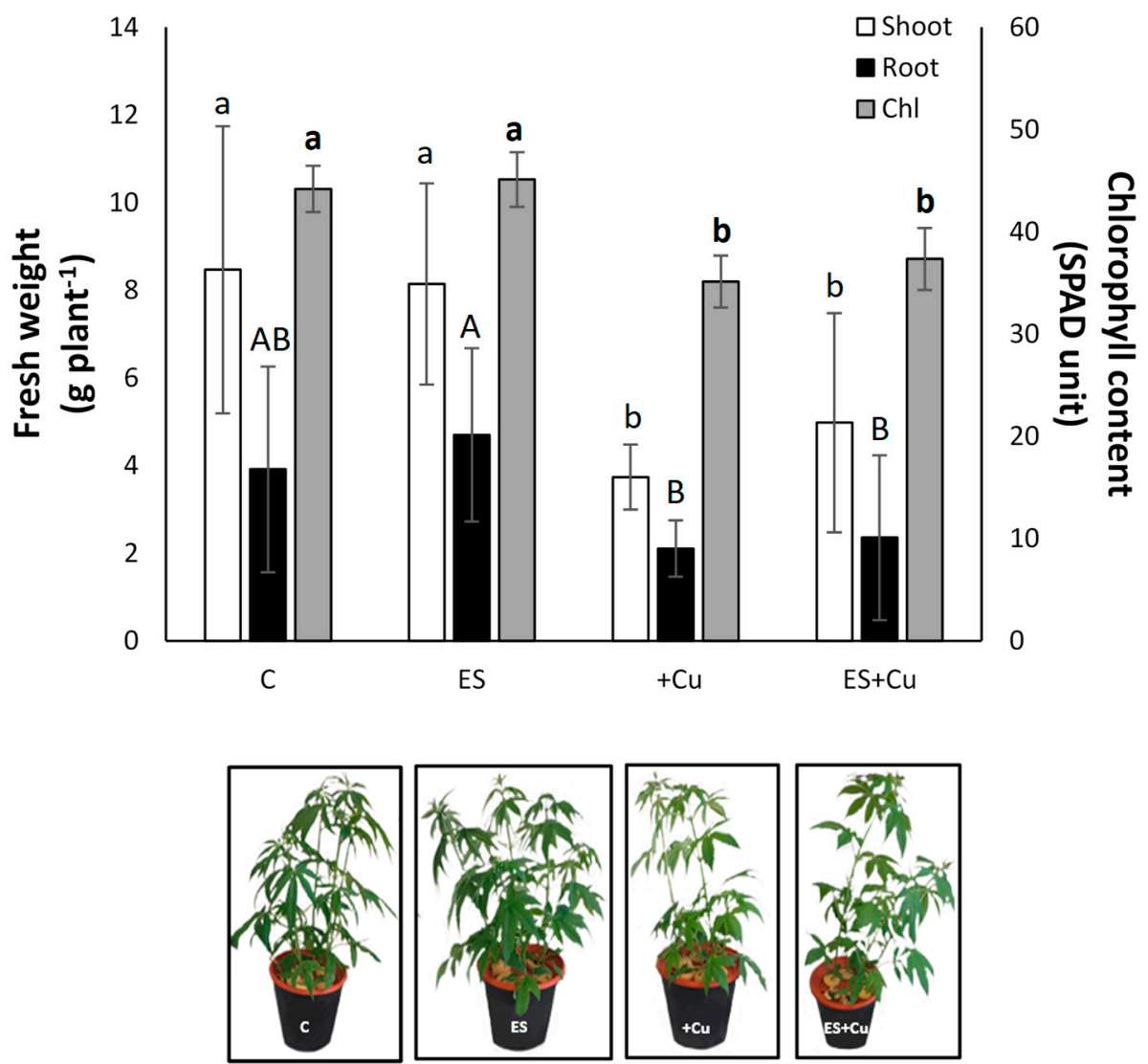

Figure 1. Fresh weight of shoots (white bars) and roots (black bars), and chlorophyll (Chl) content (grey bars) of hemp plants grown hydroponically in four different growth conditions: control $\left(\mathrm{C}=1.2 \mathrm{mM}\right.$ sulfate and $\left.0.2 \mu \mathrm{M} \mathrm{CuSO}_{4}\right)$; sulfate treatment $(\mathrm{ES}=2.4 \mathrm{mM}$ sulfate and $0.2 \mu \mathrm{M}$ $\left.\mathrm{CuSO}_{4}\right)$; excess $\mathrm{Cu}\left(+\mathrm{Cu}=1.2 \mathrm{mM}\right.$ sulfate and $\left.20 \mu \mathrm{M} \mathrm{CuSO}_{4}\right)$; excess $\mathrm{Cu}$ and sulfate treatment $\left(\mathrm{ES}+\mathrm{Cu}=2.4 \mathrm{mM}\right.$ sulfate and $\left.20 \mu \mathrm{M} \mathrm{CuSO}_{4}\right)$. Below graph, pictures of 21-day-old hemp plants exposed to the four different growth conditions. Data are reported as mean $\pm \mathrm{SD}$ of three independent replicates $(n=3)$. The statistical significance was determined by one-way ANOVA analysis with LSD post hoc test $(p<0.05)$. Different lower-case, upper-case, and bold lower-case letters indicate significantly different values among the fresh weights in shoots and roots, and Chl content, respectively.

As expected, $\mathrm{Cu}$ concentration increased in plant exposed to $\mathrm{Cu}$ stress (sole or in combination with sulfate treatment) (Figure 2B). In particular, $\mathrm{Cu}$ accumulation was higher in the roots than in the shoots in both $+\mathrm{Cu}$ and $\mathrm{ES}+\mathrm{Cu}$ condition (Figure 2B). Interestingly, the $\mathrm{Cu}$ excess treatment combined with the sulfate one (ES + $\mathrm{Cu}$ condition) led to lower shoot accumulation of $\mathrm{Cu}(-36 \%$ with respect to $+\mathrm{Cu}$ condition) (Figure 2B). On the other hand, no significant difference in $\mathrm{Cu}$ accumulation was observed between ES condition and $\mathrm{C}$ condition both in shoots and in roots (Figure 2B).

The $\mathrm{Cu}$-treated plants showed a lower Fe accumulation in the shoots $(-34 \%$ and $-37 \%$ in $+\mathrm{Cu}$ and $\mathrm{ES}+\mathrm{Cu}$ conditions, respectively) as compared to the control (Figure $2 \mathrm{C}$ ). Conversely, the Fe concentration increased significantly in the shoots of ES plants $(+18 \%$ with respect to control C) (Figure 2C).

Figure 2D shows that treatment with $\mathrm{Cu}$ also significantly affected $\mathrm{Mn}$ accumulation. In particular, a significant drop of $\mathrm{Mn}$ concentration was observed in the roots of $+\mathrm{Cu}$ plants $(-67 \%)$ as well as in the shoots of ES+Cu plants $(-44 \%)$ compared to the values measured in control plants. 


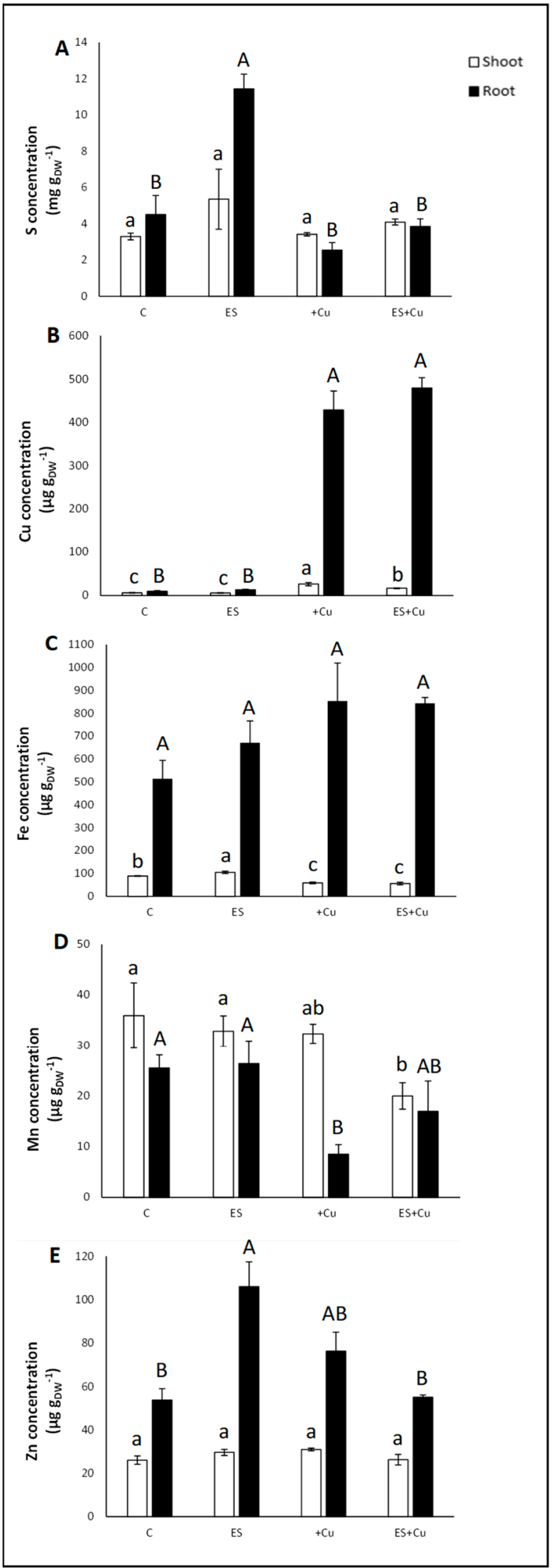

Figure 2. Sulfur (A), $\mathrm{Cu}(\mathbf{B}), \mathrm{Fe}(\mathrm{C}) \mathrm{Mn}(\mathrm{D})$, and $\mathrm{Zn}(\mathrm{E})$ concentration detected in shoots (white bars) and roots (black bars) of hemp plants grown hydroponically as described in Figure 1. Statistics as in Figure 1. 
Data reported here highlight that the $\mathrm{Cu}$ treatment did not significantly affect $\mathrm{Zn}$ accumulation in hemp plants regardless of sulfate supply (Figure 2E). However, plants grown in the ES condition exhibited a higher capability to accumulate $\mathrm{Zn}$ at root level (+97\% as compared to the control) (Figure 2E).

The PCA analysis was applied for each set of nutrient concentration data $(\mathrm{Ca}, \mathrm{Cu}, \mathrm{Fe}$, $\mathrm{Mg}, \mathrm{Mn}, \mathrm{Mo}, \mathrm{P}, \mathrm{S}$, and $\mathrm{Zn}$ ) measured in the shoots and roots of hemp plants grown under the four growth conditions, with the aim of distinguishing different metal accumulation performances as a function of the growth condition (Figure 3A,B).
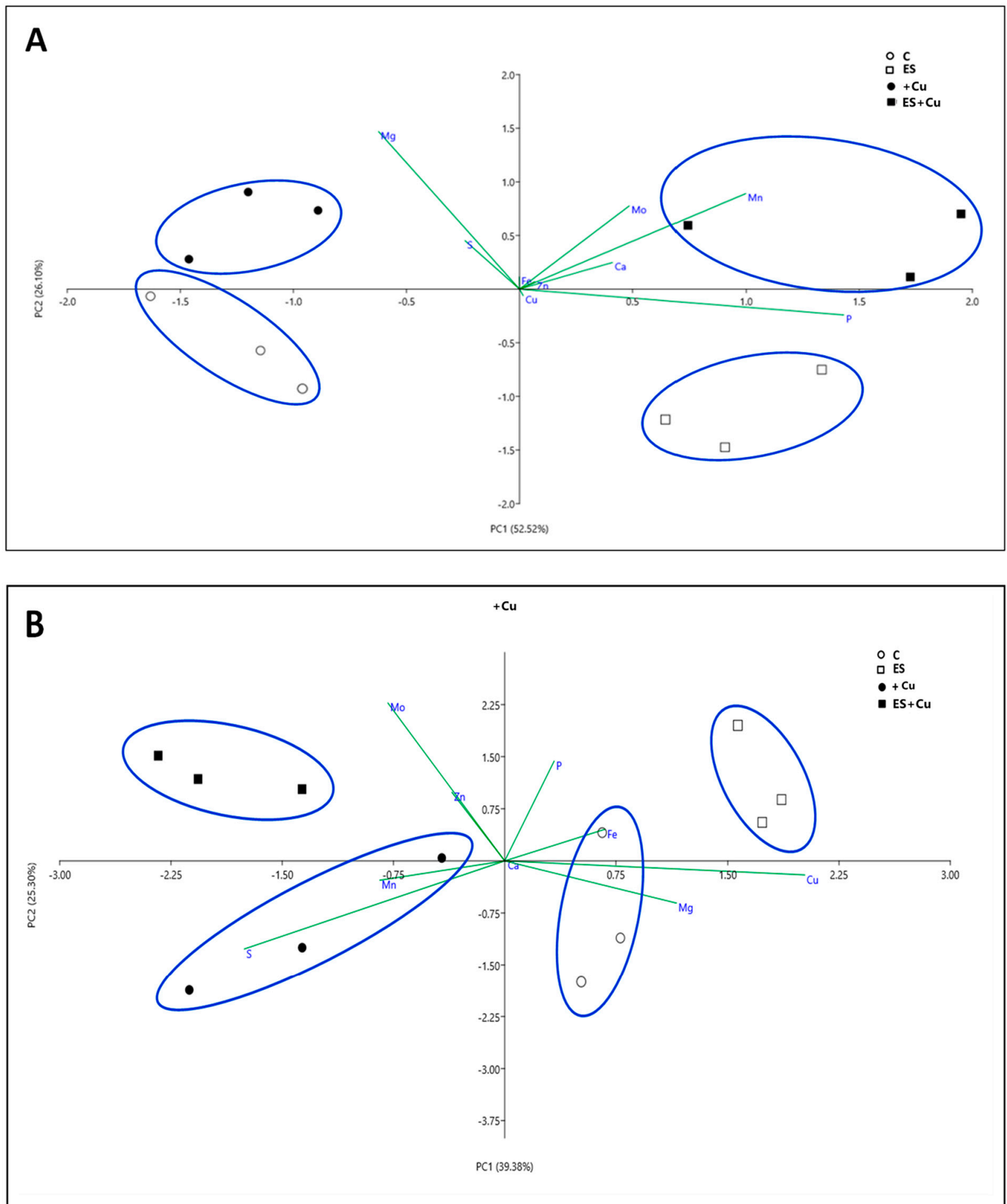

Figure 3. Principal component analysis (PCA) scatter plot of shoot (A) and root (B) ionome of hemp plants grown hydroponically as described in Figure 1. 
Results for shoots are reported in Figure 3A, where the first two components, used to build the scatter plot, represented $78.62 \%$ of the total variance. The four different growth conditions $(\mathrm{C}, \mathrm{ES},+\mathrm{Cu}$, and $\mathrm{ES}+\mathrm{Cu}$ ) clustered in four distinct groups (Figure 3A). Along the first component (PC1), representing 52.52\% of the total variance, the groups were distinguished according to the sulfate supply in the NS (i.e., $+\mathrm{Cu}$ vs. ES + Cu and C vs. ES). Along the second component (PC2), representing $26.10 \%$ of the total variance, the groups were distinguished in function of the $\mathrm{Cu}$ concentration in the $\mathrm{NS}$ (i.e., $+\mathrm{Cu}$ vs. $\mathrm{C}$ and $\mathrm{ES}+$ Cu vs. ES) (Figure 3A). Considering PC1, the positive contribution to the separation was given mostly by $\mathrm{P}$ (Figure S1). Only $\mathrm{Mg}$ and S concentrations contributed negatively to the separation along PC1 (Figure S1). Considering PC2, mainly Mg drove the distribution along the positive direction of the axis, while only $\mathrm{P}$ and $\mathrm{Cu}$ concentrations were the drivers for the negative direction of the axis (Figure S2).

When the PCA analysis was carried out with the ionome profile of hemp roots, the first two components described $64.68 \%$ of the total variance and the corresponding scatter plot is shown in Figure 3B. The PCA still clearly displays the separation of the four different growth conditions $(C, E S,+C u$, and $E S+C u$ ) in four distinct clusters (Figure 3B). In this case, $\mathrm{PC} 1$, representing $39.38 \%$ of the total variance, separated the different growth conditions as a function of the $\mathrm{Cu}$ concentration in the NS (i.e., $\mathrm{ES}+\mathrm{Cu}$ vs. $\mathrm{ES}$ and $+\mathrm{Cu}$ vs. $\mathrm{C}$ ). On the other hand, PC2, representing $25.30 \%$ of the total variance, separated the different growth conditions according to the sulfate concentration in the NS (i.e., ES + $\mathrm{Cu}$ vs. + $\mathrm{Cu}$ and ES vs. C) (Figure 3B). Along PC1, the positive influence for the distribution was given to a large extent by $\mathrm{Cu}$, while the negative influence primarily by $\mathrm{S}$ concentration (Figure S3). Along PC2, the highest positive and negative influence for the distribution by nutrients was given by Mo and S, respectively (Figure S4).

\subsection{Malondialdehyde Content}

Malondialdehyde is one of the most common biomarkers of lipid peroxidation, an oxidative damage affecting the functionality of cell membranes. Figure 4 shows that the MDA content in shoots and roots was not significantly influenced neither by the Cu toxicity nor by the sulfate availability in the NS, except for shoots from plants exposed to ES condition, where this parameter was increased by $13 \%$ compared to the control shoots (Figure 4).

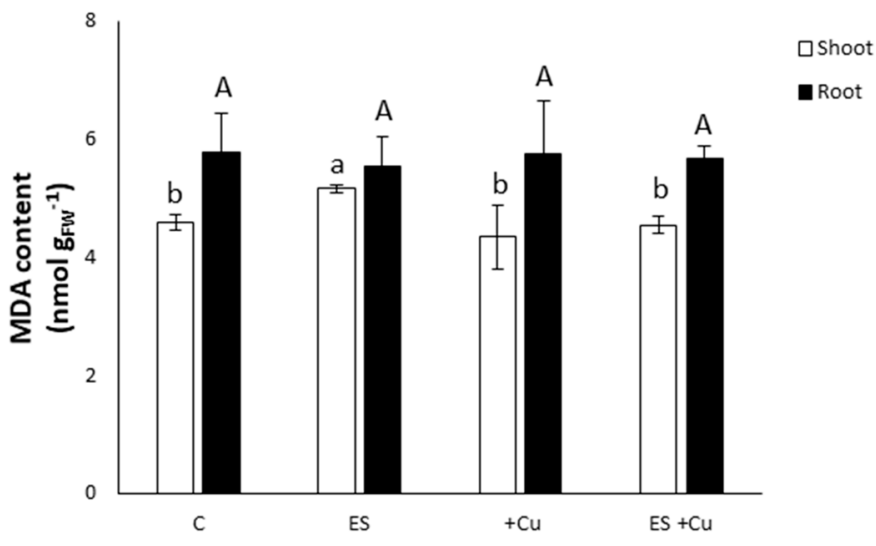

Figure 4. Malondialdehyde (MDA) content in shoots (white bars) and roots (black bars) of hemp plants. Growth conditions and statistics as in Figure 1.

\subsection{Non-Protein Thiols Content and OASTL Activity Rate}

Copper excess in the NS resulted in thiols levels $92 \%$ and $48 \%$ higher than control in both shoots and roots, respectively (Figure 5A). However, when $\mathrm{Cu}$ stress was imposed together with the sulfate treatment (ES + Cu condition), there was no accumulation of thiols in both shoot and root tissues, showing values similar to those of control ( $\mathrm{C}$ condition) samples (Figure 5A). 


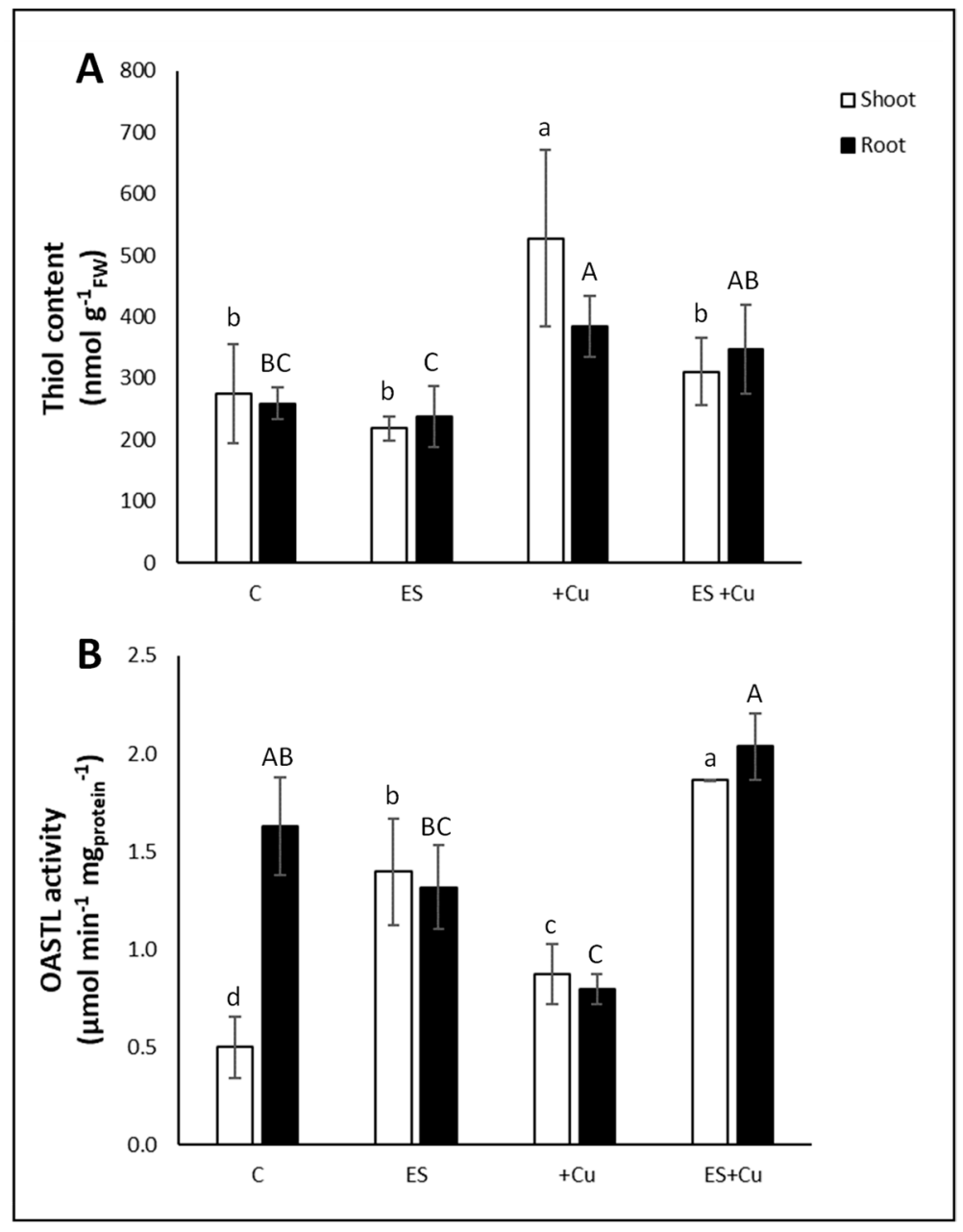

Figure 5. Thiol content (A) and $O$-acetylserine(thiol)lyase (OASTL) activity (B) in shoots (white bars) and roots (black bars) of hemp plants. Growth conditions and statistics as in Figure 1.

In shoots, OASTL activity was stimulated in all the three different growth conditions in the following order: $\mathrm{ES}+\mathrm{Cu}$ condition $(+274 \%)>\mathrm{ES}$ condition $(+180 \%)>+\mathrm{Cu}$ condition $(+75 \%)$, compared to $\mathrm{C}$ condition (Figure $5 \mathrm{~B})$. On the other hand, OASTL activity in roots of plants from both ES and ES + Cu conditions was consistently similar to that of control roots, whereas in $+\mathrm{Cu}$ roots it was significantly decreased (-51\%) (Figure 5B).

\section{Discussion}

It is widely demonstrated that an excess of $\mathrm{Cu}$ availability in the growing medium negatively impacts plant growth and development, making $\mathrm{Cu}$-contaminated soils unsuitable for the cultivation of food crops $[8,9,15]$. Considering the relevant and urgent challenges of the agricultural sector (i.e., transition towards sustainability as well as food safety and security for an increasing human population), here we evaluated the possibility of exploiting Cu-contaminated soils for the cultivation of energy crops, such as hemp [32,33]. Furthermore, being $\mathrm{S}$ directly involved in plant response to oxidative stress and nutritional disorders [34], the hypothesis that sulfate treatment could trigger plant $\mathrm{Cu}$ tolerance has been tested $[8,23]$.

The results presented for the growth of hemp plants (measured in terms of change in fresh weight of shoots and roots after exposure to the four different treatments) clearly indicated that only shoot growth was strongly reduced by high $\mathrm{Cu}$ concentration (both $+\mathrm{Cu}$ and ES + Cu condition) (Figure 1). This result seems to be consistent with the suggestion that underground stresses usually lead to a decrease in biomass allocation to shoots in favor of roots, in order to compete more effectively for water and soil nutrients [35]. 
Leaf chlorosis is the most frequent and the first symptom appearing of $\mathrm{Cu}$ toxicity $[8,17]$. Accordingly, in the present work, chlorophyll content was significantly reduced in the leaves of both plants from $+\mathrm{Cu}$ condition and from $\mathrm{ES}+\mathrm{Cu}$ one. However, a lower decrease could be observed between ES $+\mathrm{Cu}$ and control plants $(-15 \%)$ than between $+\mathrm{Cu}$ and control plants $(-20 \%)$ (Figure 1). This effect might be considered a protective action of sulfate at the level of chlorophyll biosynthesis against $\mathrm{Cu}$ toxicity $[27,36]$.

As expected, $\mathrm{Cu}$ concentration increased in plants exposed to $\mathrm{Cu}$ treatment (Figure 2B). Interestingly, excess $\mathrm{Cu}$ combined with sulfate treatment (ES + $\mathrm{Cu}$ condition) resulted in a lower shoot $\mathrm{Cu}$ accumulation with respect to the $+\mathrm{Cu}$ condition (Figure 2B), suggesting a role of $\mathrm{S}$ in $\mathrm{Cu}$ allocation within the plant and its homeostasis.

Excess $\mathrm{Cu}$ also impairs the acquisition processes of other nutrients, leading to plant nutritional imbalances $[17,20,22,37]$, due to either limited uptake, known as "phenomenon of inducible deficiency", or increased acquisition [37]. For instance, plant capability to accumulate $\mathrm{S}$ and $\mathrm{Zn}$ was not affected by $\mathrm{Cu}$ treatment (both single and combined with sulfate) (Figure 2A,E, respectively). On the other hand, exposure to excess $\mathrm{Cu}$ reduced $\mathrm{Fe}$ accumulation in shoot tissues (Figure 2C). The finding that root Fe concentration was not affected by $\mathrm{Cu}$ treatment could be explained considering that a huge Fe amount is present in this tissue in the apoplasm as an extraplasmatic pool [38,39]. However, the existence of competition phenomena among nutrients affecting Fe uptake and, then, its translocation to the shoot cannot be excluded $[40,41]$.

It is also interesting to note that a limited $\mathrm{Mn}$ accumulation has been measured in the presence of $\mathrm{Cu}$ in the NS in $+\mathrm{Cu}$ roots and in $\mathrm{ES}+\mathrm{Cu}$ shoots, projecting a potential risk for the activation of endogenous crop defense systems [42] (Figure 2D).

Plant responses in terms of nutrient uptake may depend on the plant species, the metal concentration to which plants are exposed, and the mechanisms of competition among nutrients occurring at the root plasma membrane level [43]. The root uptake of $\mathrm{Cu}$ is essentially mediated by the COPT1 transporter [44], although transporters belonging to the ZIP family [45] as well as the Fe transporter (IRT1) [46] are certainly involved in this process. Therefore, it cannot be excluded that competition phenomena with other essential elements (specifically $\mathrm{Fe}$ ) can occur in case of increased $\mathrm{Cu}$ concentration in the rhizosphere [8].

Principal component analysis revealed a clear separation of the four different conditions with respect to $\mathrm{Cu}$ or $\mathrm{S}$ treatment, suggesting that there were significant ionomic differences among the groups (Figure 3A,B). Interestingly, $\mathrm{Cu}$ was positively correlated with the second axis (PC2) in the shoot ionome and negatively correlated with the first axis (PC1) in the root ionome (Figure 3A,B, respectively).

Although high $\mathrm{Cu}$ availability in the growing medium interferes with root Fe uptake, some studies have shown that the treatment with Fe could alleviate the deleterious effects of $\mathrm{Cu}$ [47]. On the other hand, antagonistic uptake phenomena between $\mathrm{Mg}$ vs. $\mathrm{Cu}$ and $\mathrm{Ca}$ vs. $\mathrm{Cu}$ have been reported, suggesting that treatments with $\mathrm{Mg}$ or $\mathrm{Ca}$ can mitigate $\mathrm{Cu}$ toxicity, thus promoting the growth and development of different plant species [48-50].

Most remarkably, a significant increase in both Fe (Figure 2C) and Zn (Figure 2E) accumulation was found in ES shoots and roots, respectively, confirming other recent studies where the $\mathrm{S}$ benefits for Fe and $\mathrm{Zn}$ accumulation in durum wheat plants have been demonstrated [34]. The enhancement of Fe accumulation in plants exposed to high $S$ supply could originate from a response mechanism based on an increased availability of S-containing metabolites, which are precursors for the synthesis of nicotianamine, ethylene, and phytosiderophores playing a key role in the improvement of Fe uptake activity [51,52].

Copper stress leads to increased production and accumulation of ROS, such as the superoxide radical $\left(\mathrm{O}_{2}{ }^{-}\right)$and hydrogen peroxide $\left(\mathrm{H}_{2} \mathrm{O}_{2}\right)$ [53]. These free radicals are usually present in cells as intermediate products of various metabolic pathways, but they represent a serious problem under stress conditions since their increased concentration can damage biological structures and alter the functionality of the cells and tissues, specifically by oxidizing lipids of plasma membranes [54]. The oxidative action on lipids proceeds by a 
radical chain mechanism known as lipid peroxidation. The main targets of this process are polyunsaturated fatty acids, which are present in high concentrations in phospholipids of plasma membranes [55]. One of the biomarkers commonly used for the evaluation of the level of lipid peroxidation is MDA, which is a highly toxic by-product generated by lipid peroxidation [56]. In the present study, $\mathrm{Cu}$ stress (both $+\mathrm{Cu}$ and $\mathrm{ES}+\mathrm{Cu}$ condition) did not significantly affect MDA content in both shoots and roots of hemp plants (Figure 4), suggesting that hemp plants are able to cope efficiently with oxidative stress. Overall, plants have complex defense systems to avoid or, at least, limit the heavy metal-induced oxidative damage. These systems can be enzymatic and non-enzymatic [57]. Among the non-enzymatic systems, ascorbic acid and glutathione are the compounds primarily involved in defense mechanisms against oxidative stress. Glutathione is a non-protein thiol with antioxidant properties [58]. Consequently, exposure of hemp plants to $\mathrm{Cu}$ could require an enhanced metabolic demand for reduced S (i.e., thiols), through an increased sulfate assimilation rate. Accordingly, the thiol level reached the highest values in both shoots and roots of Cu-treated plants (+Cu condition) (Figure 5A). However, the combination of $\mathrm{Cu}$ treatment with sulfate one (ES + Cu condition) did not lead to improved thiol content compared to the control (Figure 5A). To evaluate whether the increased thiol production induced by the $\mathrm{Cu}$ stress alone was related to an increase in the plant ability to assimilate sulfate, changes in OASTL activity in shoots and roots of hemp plants were analyzed. This enzyme catalyzes the last $\mathrm{S}$ assimilation reaction, leading to the synthesis of cysteine from $\mathrm{O}$-acetylserine and inorganic sulfide [59]. In our study, the activity of OASTL was increased by $\mathrm{Cu}$ treatment (both single and combined) in shoots, whereas it was unaffected in plants exposed to combined treatment and even decreased in $+\mathrm{Cu}$ roots (Figure 5B). This different behavior of OASTL activity between shoots and roots could be explained considering that the sulfate assimilation occurs mainly at shoot level [60]. Thus, our results are consistent with the hypothesis of thiols translocation from shoots to roots, where their accumulation is known to inhibit root sulfate uptake and assimilation [61,62].

\section{Conclusions}

In conclusion, the present results suggest that hemp plants possess a good ability to adapt to the presence of high $\mathrm{Cu}$ concentrations in the growth medium, suggesting that soils with impaired fertility, such as those characterized by high $\mathrm{Cu}$ contents, can represent a valid opportunity at least for the cultivation of energy crops.

Furthermore, although $\mathrm{S}$ metabolism is involved in the plant response to face $\mathrm{Cu}$ toxicity, it remains to be clarified whether the use of exogenous sulfate may represent an agronomic practice to improve crop performance under these edaphic conditions.

The agriculture transition toward sustainability and the Sustainable Development Goals proposed by United Nation in the 2030 Agenda (https:/ /sdgs.un.org/goals accessed on 26 July 2021) is yet to be achieved, but these findings could represent a valuable opportunity contributing to realize this goal.

Supplementary Materials: The following are available online at https:/ /www.mdpi.com/article/10 .3390/environments8110111/s1, Figure S1: principal component analysis (PCA) loading plot along PC1 of shoot ionome of hemp plants, Figure S2: principal component analysis (PCA) loading plot along PC2 of shoot ionome of hemp plants, Figure S3: principal component analysis (PCA) loading plot along PC1 of root ionome of hemp plants, Figure S4: principal component analysis (PCA) loading plot along PC2 of root ionome of hemp plants.

Author Contributions: Conceptualization, S.A.; data curation, S.C. (Silvia Celletti); formal analysis, G.Q., S.C. (Silvia Celletti) and E.C.; investigation, G.Q., S.C. (Silvia Celletti) and E.C.; methodology, S.A.; resources, T.M. and S.A.; supervision, S.A.; visualization, S.C. (Silvia Celletti); writing-original draft, G.Q., S.C. (Silvia Celletti) and S.A.; writing-review and editing, S.C. (Silvia Celletti), T.M., S.C. (Stefano Cesco) and S.A. All authors have read and agreed to the published version of the manuscript.

Funding: The research was carried out in the frame of the MIUR (Ministry of Education, University and Research) initiative "Department of Excellence" (Law 232/2016). 
Conflicts of Interest: The authors declare no conflict of interest.

\section{References}

1. Directive 2009/28/EC. Available online: https:/ / www.buildup.eu/en/practices/publications/directive-200928ec-promotionuse-energy-renewable-sources-23-april-2009 (accessed on 11 May 2021).

2. Tilman, D.; Reich, P.B.; Knops, J.M.H. Biodiversity and ecosystem stability in a decade-long grassland experiment. Nature 2006, 441, 629-632. [CrossRef]

3. Baffes, J.; Haniotis, T. Placing the 2006/08 Commodity Price Boom into Perspective; Policy Research Working Papers; The World Bank: Washington, DC, USA, 2010.

4. Fagnano, M.; Boccia, L.; Pindozzi, S.; Infascelli, R.; Augno, S. Aree potenzialmente convertibili a colture energetiche: Caso studio della Regione Campania. In Proceedings of the XLI Convegno Società Italiana di Agronomia, Bari, Italy, 19-21 September 2012; pp. 464-466.

5. Tóth, G.; Montanarella, L.; Rusco, E. Threats to Soil Quality in Europe 2008; European Communities: Luxembourg, 2008.

6. Wang, R.; Shafi, M.; Ma, J.; Zhong, B.; Guo, J.; Hu, X.; Xu, W.; Yang, Y.; Ruan, Z.; Wang, Y.; et al. Effect of amendments on contaminated soil of multiple heavy metals and accumulation of heavy metals in plants. Environ. Sci. Pollut. Res. 2018, 25, 28695-28704. [CrossRef] [PubMed]

7. Marschner, P. Marschner's Mineral Nutrition of Higher Plants; Marschner, P., Ed.; Elselvier Ltd.: Amsterdam, The Netherlands, 2012.

8. Brunetto, G.; de Melo, G.W.B.; Terzano, R.; Del Buono, D.; Astolfi, S.; Tomasi, N.; Pii, Y.; Mimmo, T.; Cesco, S. Copper accumulation in vineyard soils: Rhizosphere processes and agronomic practices to limit its toxicity. Chemosphere 2016, 162, 293-307. [CrossRef] [PubMed]

9. Cesco, S.; Pii, Y.; Borruso, L.; Orzes, G.; Lugli, P.; Mazzetto, F.; Genova, G.; Signorini, M.; Brunetto, G.; Terzano, R.; et al. A Smart and Sustainable Future for Viticulture is Rooted in Soil: How to Face Cu Toxicity. Appl. Sci. 2021, 11, 907. [CrossRef]

10. Komárek, M.; Čadková, E.; Chrastný, V.; Bordas, F.; Bollinger, J.C. Contamination of vineyard soils with fungicides: A review of environmental and toxicological aspects. Environ. Int. 2010, 36, 138-151. [CrossRef]

11. Tóth, G.; Hermann, T.; Da Silva, M.R.; Montanarella, L. Heavy metals in agricultural soils of the European Union with implications for food safety. Environ. Int. 2016, 88, 299-309. [CrossRef]

12. Shabbir, Z.; Sardar, A.; Shabbir, A.; Abbas, G.; Shamshad, S.; Khalid, S.; Natasha; Murtaza, G.; Dumat, C.; Shahid, M. Copper uptake, essentiality, toxicity, detoxification and risk assessment in soil-plant environment. Chemosphere 2020, 259, 127436. [CrossRef]

13. Blume, H.-P.; Brümmer, G.W.; Fleige, H.; Horn, R.; Kandeler, E.; Kögel-Knabner, I.; Kretzschmar, R.; Stahr, K.; Wilke, B.-M Scheffer/Schachtschabel Soil Science; Springer: Berlin/Heidelberg, Germany, 2016; ISBN 9783642309410.

14. Rehman, M.; Liu, L.; Wang, Q.; Saleem, M.H.; Bashir, S.; Ullah, S.; Peng, D. Copper environmental toxicology, recent advances, and future outlook: A review. Environ. Sci. Pollut. Res. 2019, 26, 18003-18016. [CrossRef]

15. Miotto, A.; Ceretta, C.A.; Brunetto, G.; Nicoloso, F.T.; Girotto, E.; Farias, J.G.; Tiecher, T.L.; De Conti, L.; Trentin, G. Copper uptake, accumulation and physiological changes in adult grapevines in response to excess copper in soil. Plant. Soil 2014, 374, 593-610. [CrossRef]

16. Ravet, K.; Pilon, M. Copper and Iron Homeostasis in Plants: The Challenges of Oxidative Stress. Antioxid. Redox Signal. 2013, 19, 919-932. [CrossRef]

17. Feil, S.B.; Pii, Y.; Valentinuzzi, F.; Tiziani, R.; Mimmo, T.; Cesco, S. Copper toxicity affects phosphorus uptake mechanisms at molecular and physiological levels in Cucumis sativus plants. Plant. Physiol. Biochem. 2020, 157, 138-147. [CrossRef]

18. Baldi, E.; Miotto, A.; Ceretta, C.A.; Quartieri, M.; Sorrenti, G.; Brunetto, G.; Toselli, M. Soil-applied phosphorous is an effective tool to mitigate the toxicity of copper excess on grapevine grown in rhizobox. Sci. Hortic. 2018, 227, 102-111. [CrossRef]

19. De Conti, L.; Cesco, S.; Mimmo, T.; Pii, Y.; Valentinuzzi, F.; Melo, G.W.B.; Ceretta, C.A.; Trentin, E.; Marques, A.C.; Brunetto, G. Iron fertilization to enhance tolerance mechanisms to copper toxicity of ryegrass plants used as cover crop in vineyards. Chemosphere 2020, 243, 125298. [CrossRef]

20. Marastoni, L.; Sandri, M.; Pii, Y.; Valentinuzzi, F.; Brunetto, G.; Cesco, S.; Mimmo, T. Synergism and antagonisms between nutrients induced by copper toxicity in grapevine rootstocks: Monocropping vs. intercropping. Chemosphere 2019, 214, 563-578. [CrossRef]

21. Marastoni, L.; Tauber, P.; Pii, Y.; Valentinuzzi, F.; Astolfi, S.; Simoni, A.; Brunetto, G.; Cesco, S.; Mimmo, T. The potential of two different Avena sativa L. cultivars to alleviate Cu toxicity. Ecotoxicol. Environ. Saf. 2019, 182, 109430. [CrossRef]

22. Monni, S.; Salemaa, M.; White, C.; Tuittila, E.; Huopalainen, M. Copper resistance of Calluna vulgaris originating from the pollution gradient of a Cu-Ni smelter, in southwest Finland. Environ. Pollut. 2000, 109, 211-219. [CrossRef]

23. Rauser, W.E. Structure and function of metal chelators produced by plants. Cell Biochem. Biophys. 1999, 31, 19-48. [CrossRef] [PubMed]

24. Rheay, H.T.; Omondi, E.C.; Brewer, C.E. Potential of hemp (Cannabis sativa L.) for paired phytoremediation and bioenergy production. GCB Bioenergy 2021, 13, 525-536. [CrossRef]

25. Ahmad, R.; Tehsin, Z.; Malik, S.T.; Asad, S.A.; Shahzad, M.; Bilal, M.; Shah, M.M.; Khan, S.A. Phytoremediation Potential of Hemp (Cannabis sativa L.): Identification and Characterization of Heavy Metals Responsive Genes. CLEAN Soil Air Water 2015, 44, 195-201. [CrossRef] 
26. Meers, E.; Ruttens, A.; Hopgood, M.; Lesage, E.; Tack, F.M.G. Potential of Brassic rapa, Cannabis sativa, Helianthus annuus and Zea mays for phytoextraction of heavy metals from calcareous dredged sediment derived soils. Chemosphere 2006, 61, 561-572. [CrossRef]

27. Celletti, S.; Paolacci, A.R.; Mimmo, T.; Pii, Y.; Cesco, S.; Ciaffi, M.; Astolfi, S. The effect of excess sulfate supply on iron accumulation in three graminaceous plants at the early vegetative phase. Environ. Exp. Bot. 2016, 128, 31-38. [CrossRef]

28. Celletti, S.; Astolfi, S.; Guglielmo, N.; Colla, G.; Cesco, S.; Mimmo, T. Evaluation of a Legume-Derived Protein Hydrolysate to Mitigate Iron Deficiency in Plants. Agronomy 2020, 10, 1942. [CrossRef]

29. Ajmal Bashir, M.; Silvestri, C.; Coppa, E.; Brunori, E.; Cristofori, V.; Rugini, E.; Ahmad, T.; Hafiz, I.A.; Abbasi, N.A.; Shah, M.K.N.; et al. Response of Olive Shoots to Salinity Stress Suggests the Involvement of Sulfur Metabolism. Plants 2021, 10, 350. [CrossRef] [PubMed]

30. Celletti, S.; Pii, Y.; Mimmo, T.; Cesco, S.; Astolfi, S. The characterization of the adaptive responses of durum wheat to different Fe availability highlights an optimum Fe requirement threshold. Plant. Physiol. Biochem. 2016, 109, 300-307. [CrossRef] [PubMed]

31. Bradford, M.M. A rapid and sensitive method for the quantitation of microgram quantities of protein utilizing the principle of protein-dye binding. Anal. Biochem. 1976, 72, 248-254. [CrossRef]

32. Duke, J.A. Handbook of Energy Crops 1983; CABI: Wallingford, UK, 1983.

33. Crini, G.; Lichtfouse, E.; Chanet, G.; Morin-Crini, N. Applications of hemp in textiles, paper industry, insulation and building materials, horticulture, animal nutrition, food and beverages, nutraceuticals, cosmetics and hygiene, medicine, agrochemistry, energy production and environment: A review. Environ. Chem. Lett. 2020, 18, 1451-1476. [CrossRef]

34. Astolfi, S.; Celletti, S.; Vigani, G.; Mimmo, T.; Cesco, S. Interaction Between Sulfur and Iron in Plants. Front. Plant Sci. 2021, 12, 1-11. [CrossRef]

35. Xiong, Z.T.; Li, Y.H.; Xu, B. Nutrition Influence on Copper Accumulation by Brassica pekinensis Rupr. Ecotoxicol. Environ. Saf. 2002, 53, 200-205. [CrossRef]

36. Astolfi, S.; Pii, Y.; Terzano, R.; Mimmo, T.; Celletti, S.; Allegretta, I.; Lafiandra, D.; Cesco, S. Does Fe accumulation in durum wheat seeds benefit from improved whole-plant sulfur nutrition? J. Cereal Sci. 2018, 83, 74-82. [CrossRef]

37. Astolfi, S.; Ortolani, M.R.; Catarcione, G.; Paolacci, A.R.; Cesco, S.; Pinton, R.; Ciaffi, M. Cadmium exposure affects iron acquisition in barley (Hordeum vulgare) seedlings. Physiol. Plant. 2014, 152, 646-659. [CrossRef]

38. Cesco, S.; Nikolic, M.; Römheld, V.; Varanini, Z.; Pinton, R. Uptake of 59Fe from soluble 59Fe-humate complexes by cucumber and barley plants. Plant. Soil 2002, 241, 121-128. [CrossRef]

39. Strasser, O.; Köhl, K.; Römheld, V. Overestimation of apoplastic Fe in roots of soil grown plants. Plant. Soil 1999, 210, 179-189. [CrossRef]

40. Waters, B.M.; McInturf, S.A.; Stein, R.J. Rosette iron deficiency transcript and microRNA profiling reveals links between copper and iron homeostasis in Arabidopsis thaliana. J. Exp. Bot. 2012, 63, 5903-5918. [CrossRef]

41. Peng, H.; Wang-Müller, Q.; Witt, T.; Malaisse, F.; Küpper, H. Differences in copper accumulation and copper stress between eight populations of Haumaniastrum katangense. Environ. Exp. Bot. 2012, 79, 58-65. [CrossRef]

42. Cesco, S.; Tolotti, A.; Nadalini, S.; Rizzi, S.; Valentinuzzi, F.; Mimmo, T.; Porfido, C.; Allegretta, I.; Giovannini, O.; Perazzolli, M.; et al. Plasmopara viticola infection affects mineral elements allocation and distribution in Vitis vinifera leaves. Sci. Rep. 2020, 10, 1-18. [CrossRef]

43. Xu, P.; Sun, C.-X.; Ye, X.-Z.; Xiao, W.; Zhang, Q.; Wang, Q. The effect of biochar and crop straws on heavy metal bioavailability and plant accumulation in a $\mathrm{Cd}$ and $\mathrm{Pb}$ polluted soil. Ecotoxicol. Environ. Saf. 2016, 132, 94-100. [CrossRef]

44. Sancenón, V.; Puig, S.; Mira, H.; Thiele, D.J.; Peñarrubia, L. Identification of a copper transporter family in Arabidopsis thaliana. Plant. Mol. Biol. 2003, 51, 577-587. [CrossRef] [PubMed]

45. Wintz, H.; Fox, T.; Wu, Y.-Y.; Feng, V.; Chen, W.; Chang, H.-S.; Zhu, T.; Vulpe, C. Expression Profiles of Arabidopsis thaliana in Mineral Deficiencies Reveal Novel Transporters Involved in Metal Homeostasis. J. Biol. Chem. 2003, 278, 47644-47653. [CrossRef]

46. Korshunova, Y.O.; Eide, D.; Clark, W.G.; Guerinot, M.L.; Pakrasi, H.B. The IRT1 protein from Arabidopsis thaliana is a metal transporter with a broad substrate range. Plant. Mol. Biol. 1999, 40, 37-44. [CrossRef] [PubMed]

47. Kumar, P.; Tewari, R.K.; Sharma, P.N. Modulation of copper toxicity-induced oxidative damage by excess supply of iron in maize plants. Plant. Cell Rep. 2008, 27, 399-409. [CrossRef] [PubMed]

48. Lock, K.; Criel, P.; De Schamphelaere, K.A.C.; Van Eeckhout, H.; Janssen, C.R. Influence of calcium, magnesium, sodium, potassium and $\mathrm{pH}$ on copper toxicity to barley (Hordeum vulgare). Ecotoxicol. Environ. Saf. 2007, 68, 299-304. [CrossRef] [PubMed]

49. Chen, B.-C.; Ho, P.-C.; Juang, K.-W. Alleviation effects of magnesium on copper toxicity and accumulation in grapevine roots evaluated with biotic ligand models. Ecotoxicology 2013, 22, 174-183. [CrossRef] [PubMed]

50. Kinraide, T.B.; Pedler, J.F.; Parker, D.R. Relative effectiveness of calcium and magnesium in the alleviation of rhizotoxicity in wheat induced by copper, zinc, aluminum, sodium, and low pH. Plant. Soil 2004, 259, 201-208. [CrossRef]

51. Li, W.; Lan, P. The Understanding of the Plant Iron Deficiency Responses in Strategy I Plants and the Role of Ethylene in This Process by Omic Approaches. Front. Plant. Sci. 2017, 8, 40. [CrossRef]

52. Zuchi, S.; Watanabe, M.; Hubberten, H.-M.; Bromke, M.; Osorio, S.; Fernie, A.R.; Celletti, S.; Paolacci, A.R.; Catarcione, G.; Ciaffi, M.; et al. The interplay between sulfur and iron nutrition in tomato. Plant. Physiol. 2015, 169, 2624-2639. [CrossRef]

53. Noriega, G.; Caggiano, E.; Lecube, M.L.; Cruz, D.S.; Batlle, A.; Tomaro, M.; Balestrasse, K.B. The role of salicylic acid in the prevention of oxidative stress elicited by cadmium in soybean plants. BioMetals 2012, 25, 1155-1165. [CrossRef] 
54. Lobo, V.; Patil, A.; Phatak, A.; Chandra, N. Free radicals, antioxidants and functional foods: Impact on human health. Pharmacogn. Rev. 2010, 4, 118-126. [CrossRef]

55. Ayala, A.; Muñoz, M.F.; Argüelles, S. Lipid Peroxidation: Production, Metabolism, and Signaling Mechanisms of Malondialdehyde and 4-Hydroxy-2-Nonenal. Oxidative Med. Cell. Longev. 2014, 2014, 1-31. [CrossRef]

56. Yoshida, Y.; Umeno, A.; Shichiri, M. Lipid peroxidation biomarkers for evaluating oxidative stress and assessing antioxidant capacity in vivo. J. Clin. Biochem. Nutr. 2013, 52, 9-16. [CrossRef]

57. Sharma, S.S.; Dietz, K.-J. The relationship between metal toxicity and cellular redox imbalance. Trends Plant. Sci. 2009, 14, 43-50. [CrossRef]

58. Ulrich, K.; Jakob, U. The role of thiols in antioxidant systems. Free. Radic. Biol. Med. 2019, 140, 14-27. [CrossRef] [PubMed]

59. Taiz, L.; Zeiger, E. Plant Physiology, 3rd ed.; Sinauer Associates Inc.: Sunderland, MA, USA, 2003; ISBN 0-87893-823-0.

60. Howarth, J.R.; Parmar, S.; Jones, J.; Shepherd, C.E.; Corol, D.-I.; Galster, A.M.; Hawkins, N.D.; Miller, S.J.; Baker, J.M.; Verrier, P.J.; et al. Co-ordinated expression of amino acid metabolism in response to $\mathrm{N}$ and $\mathrm{S}$ deficiency during wheat grain filling. J. Exp. Bot. 2008, 59, 3675-3689. [CrossRef]

61. Davidian, J.-C.; Kopriva, S. Regulation of Sulfate Uptake and Assimilation-The Same or Not the Same? Mol. Plant. 2010, 3, 314-325. [CrossRef]

62. Lappartient, A.G.; Touraine, B. Demand-Driven Control of Root ATP Sulfurylase Activity and SO42-Uptake in Intact Canola (The Role of Phloem-Translocated Glutathione). Plant. Physiol. 1996, 111, 147-157. [CrossRef] 